\title{
Factors Influence the Choice of Mobile Apps for Transactions among Youngsters
}

\author{
A.Monilakshmane, B.Rajeswari
}

\begin{abstract}
The recent upward trend in adoption and usage of technology-enabled financial services (e-finance), reached the next level of doing financial transactions through mobile apps in large numbers. In this study, the researcher is focusing on the influence of differences in users' demographic attributes on their frequency of usage of e-finance mobile apps. Primary data collected from 400 respondents were analysed using one way ANOVA, cross tabulation, independent sample t-test in SPSS. The findings revealed that usage differences in gender, income and education qualification of users, mainly youngsters influence their choice of apps and number of transactions they perform, while age and occupation differences fail to make significant changes. This result contributes to the existing researches by proving/disproving its findings and to service providers to design their service offerings accordingly.
\end{abstract}

Keywords: e-finance, e-wallet, technology adoption, mobile apps

\section{INTRODUCTION}

Recent policy implications and economic reforms in India encouraged people to adopt and use new technology for their convenience. The Digital India campaign motivated the people to use digital platforms for their tasks which were earlier done manually. The number of people and the frequency of usage is increasing trifold due to the efforts of Cashless economy and ease of use. E-governance, e-finance, e-health, etc. are some of the fields where the Government of India created the new virtual platform or improved the existing along with transactions. Here the focus is on the sub-category of digital banking, which coming under e-finance, the payments and receipts of money using mobile applications (Apps). Both commercial banks and third parties provide these apps as a transaction platform.

Demonetisation in India further encouraged digital banking users to adopt new and innovative ideas like mobile apps for financial transactions. The usage of mobile apps for banking getting popular because of its simplicity and convenience and a growing trend in the usage of smartphones.

Revised Manuscript Received on July 22, 2019

A.Monilakshmane, Research scholar (Phd), Department of management studies, School of management, Pondicherry University, Kalapet, Puducherry - 605014. E-mail: lakshmane22@gmail.com, Mobile No.: +91 7845567545.

Dr.B.Rajeswari, Assistant Professor, Department of management studies, School of management, Pondicherry University, Kalapet, Puducherry - 605014. E-mail: raajeebster@gmail.com, Mobile No.: +91 9894422626.

\section{LITERATURE REVIEW}

A shred of empirical evidence provided by Ha et al., (2007), a demographic characteristic of a user like age, gender and income contributes a substantial part in determining new technology usage. Both age and gender measured to have an influence on internet banking adoption. However, Dong-Hee Shin (2009) revealed an absence of moderation impact of gender over mobile banking (e-wallet) adoption in Korea. Gefen, D., \& Straub, D. (1997) stated that females are more likely to adopt new technology (e-mail) compared to the male population.

Michael Harris et. al (2016) study focused on increasing age affects new technology adoption. The results revealed that the younger user was more interested in new online banking technologies. Whereas, the older generation prefers to stick with the traditional mode of banking operations. Many previous studies revealed that users' age having an adverse effect on an emerging technology adoption (Morris and Venkatesh, 2000; Lam and Lee, 2006; Chung et al., 2010).

Tui McKeown \& Mary Anderson (2016) were looked into the education qualification of the user (undergraduates comparing with postgraduates) in technology adoption (e-learning), where proven that postgraduates efficiently adopt technology compared to undergraduates. A higher education qualification denotes higher knowledge over using technology which may have a positive influence over the adoption of new technology (Thompson S.H. Teo, 2001)

\section{RESEARCH GAP}

As per previous studies' findings, many recent studies' results are contradicting previous studies' results. Earlier proven to have influenced later discovered as a non-influential variable(s). Some variable(s) which had a positive impact on usage in some studies have a negative impact on other studies involving technology adoption and usage. Therefore, studying differences in demographic variables influence on emerging new technology usage (e-finance mobile apps) in our context become vital.

\section{OBJECTIVE}

The major objective is a focus on the effect of users' demographic attributes (gender, age, income, education and occupation) on the usage of e-finance mobile apps. 
Factors Influence the Choice of Mobile Apps for Transactions among Youngsters

\begin{tabular}{|c|c|c|}
\hline Items & $\mathbf{N}$ & $\%$ \\
\hline \multicolumn{3}{|l|}{ Gender } \\
\hline Male & 287 & 71.80 \\
\hline Female & 113 & 28.20 \\
\hline \multicolumn{3}{|l|}{ Age (in years) } \\
\hline 18 to 24 & 146 & 36.50 \\
\hline 25 to 30 & 105 & 26.25 \\
\hline 31 to 36 & 83 & 20.75 \\
\hline 37 to 42 & 32 & 8.00 \\
\hline 43 to 48 & 17 & 4.25 \\
\hline $49+$ & 17 & 4.25 \\
\hline \multicolumn{3}{|l|}{ Education } \\
\hline High School & 22 & 5.50 \\
\hline Higher Secondary & 84 & 21.00 \\
\hline Diploma & 35 & 8.75 \\
\hline Undergraduate & 136 & 34.00 \\
\hline Postgraduate & 123 & 30.75 \\
\hline \multicolumn{3}{|l|}{ Occupation } \\
\hline Student & 110 & 27.50 \\
\hline Government Employee & 04 & 1.00 \\
\hline Private Employee & 96 & 24.00 \\
\hline Self-employed & 127 & 31.75 \\
\hline Others & 63 & 15.75 \\
\hline \multicolumn{3}{|l|}{ Income (per month) } \\
\hline$<$ Rs. 10000 & 160 & 40.00 \\
\hline Rs.10001 - Rs.15000 & 99 & 24.75 \\
\hline Rs.15001 - Rs.20000 & 47 & 11.75 \\
\hline Rs.20001 - Rs.25000 & 47 & 11.75 \\
\hline > Rs. 25000 & 47 & 11.75 \\
\hline
\end{tabular}

\section{RESULTS}

An outcome of descriptive statistics summarised in Table 1 , which shows the demographic profile of users. Male respondents contribute $71.80 \%$ of the total sample size (Fig. 1). Fig. 2 shows that more than $60 \%$ of respondents fall in between 18 to 30 years old. Fig. 3 reveals that $64.75 \%$ of respondent were being at least undergraduates. As shown in Fig. 4, $31.75 \%$ self-employed respondents followed by 27.5 $\%$ of students. Fig. 5 carried that $40 \%$ of respondents earn up to ten thousand Indian rupees per month.

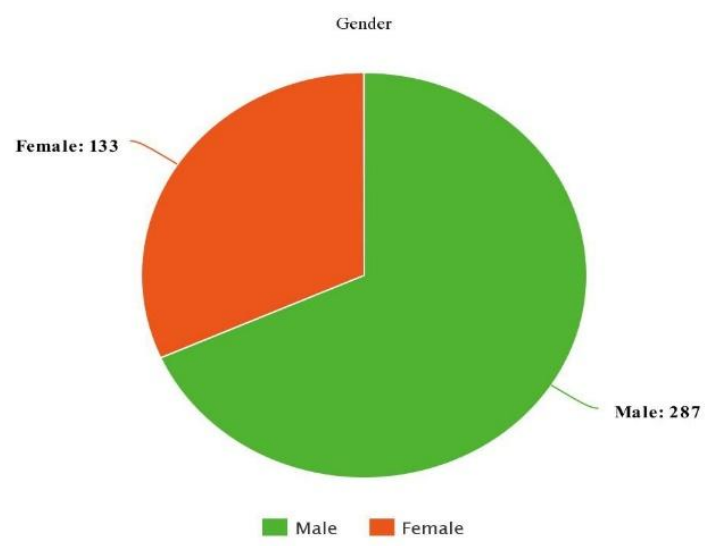

\section{Fig.1 Gender}

\section{Table 1. Demographic Profile}

\section{HYPOTHESES}

Following hypotheses are framed with reference to research objectives and a research gap.

H1: There is an effect of users' gender on the actual usage of e-finance apps.

H2: There is an effect of users' age on the actual usage of e-finance apps.

H3: There is an effect of users' income on the actual usage of e-finance apps.

H4: There is an effect of users' education on the actual usage of e-finance apps.

H5: There is an effect of users' occupation on the actual usage of e-finance apps.

\section{METHODOLOGY}

The respondents were users who used or using e-finance mobile apps to carry out financial transactions. A structured questionnaire was sent to the respondent and primary data of 400 responses collected through the online mode. We analyse the data for descriptive statistics, one way ANOVA, cross-tabulation and independent samples t-test using SPSS. 
150

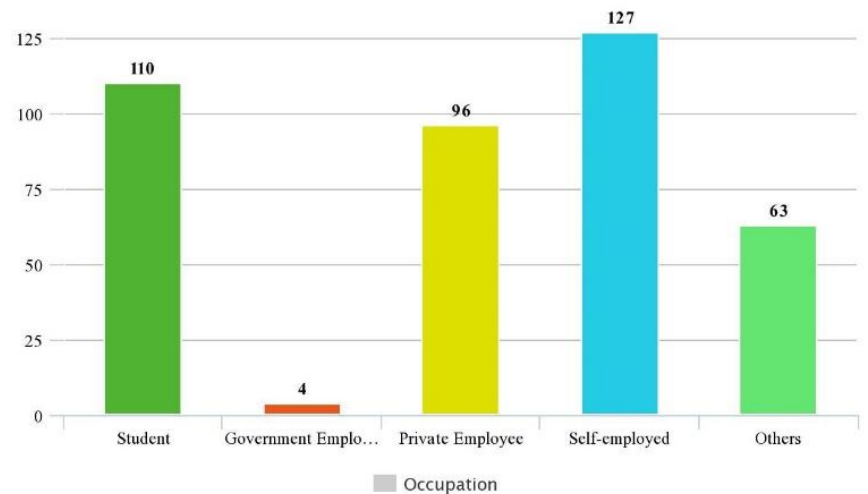

Fig.4 Occupation

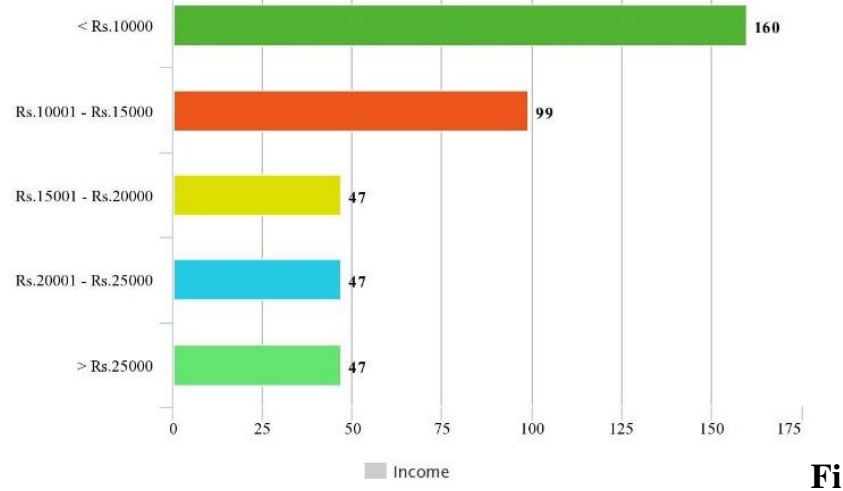

g.5 Income

\begin{tabular}{|c|c|c|}
\hline No. of years & $\mathbf{N}$ & \% \\
\hline < 1 year & 160 & 40.00 \\
\hline 1 - 2 years & 112 & 28.00 \\
\hline 2 - 3 years & 55 & 13.75 \\
\hline 3 - 4 years & 36 & 9.00 \\
\hline > 4 years & 37 & 9.25 \\
\hline
\end{tabular}

Table 2. Number of years using e-finance mobile apps

\begin{tabular}{|c|c|c|}
\hline Frequency of usage & $\mathbf{N}$ & \% \\
\hline $1-3$ times & 57 & 14.25 \\
\hline $4-6$ times & 56 & 14.00 \\
\hline $7-9$ times & 99 & 24.75 \\
\hline $10-12$ times & 76 & 19.00 \\
\hline $13-15$ times & 116 & 29.00 \\
\hline
\end{tabular}

Table 3. Number of transactions using e-finance mobile apps (in a month)

Table 2 shows how many years the respondents using e-finance mobile apps and Table 3 shows how frequent respondents transact using e-finance mobile apps in one month period. The results of cross-tabulation of gender, age, income, education and occupation with a number of transactions using e-finance mobile apps (in one month) were shown in Table 4 to Table 8 respectively.

\section{FINDINGS AND DISCUSSION}

The outcome of one-way ANOVA, cross-tabulation, independent sample t-test discussed in detail below for each hypothesis. An accepted and rejected hypotheses were summarised in Table 9.
H1: There is an effect of users' gender on the actual usage of e-finance apps.

The results reveal that, a statistically significant difference in the number of transactions between male users $(n=287, \mu$ $=3.22, \mathrm{SD}=1.45)$ and female users $(\mathrm{n}=113, \mu=3.69, \mathrm{SD}=$ $1.15), \mathrm{t}(400)=-3.373, \mathrm{p}=.001$. As per cross tabulation result shown in Table 4, Male respondents tend to do more transactions using mobile apps compared to female respondents. This finding contradicts previous research findings where gender had an insignificant role in technology adoption (Dong-Hee Shin, 2009) and female respondent uses emerging technology more often than male respondents [2].

H2: There is an effect of users' age on the actual usage of e-finance apps.

The results reveal that, no statistically significant difference in a number of transactions among users of different age groups $(\mathrm{p}>.001)$. Irrespective of the age difference among respondents, their usage pattern does not make a significant change. However, the users between 18 years to 30 years old do more transactions using e-finance apps compared to other age groups by contributing $62.75 \%$ in the whole sample as shown in Table 5.

H3: There is an effect of users' income on the actual usage of e-finance apps.

The results reveal that, a statistically significant difference in a number of transactions among users based on their income levels $(p<.001)$. As shown in Table 6 , income has a negative influence on e-finance mobile apps usage. When the income of the respondent is higher, they tend to do less number of the transaction using mobile apps. The respondents who earn a monthly income of less than fifteen thousand India rupee, interested in doing more financial transaction through mobile apps compared to any higher income groups.

H4: There is an effect of users' education on the actual usage of e-finance apps.

The results reveal that, a statistically significant difference in a number of transactions among users who had different education qualifications $(\mathrm{p}<.001)$. This finding supports previous studies [9], [11] as an education qualification goes higher, they tend to adopt new technology very easily than respondent with less education qualification. The undergraduate and postgraduates do more financial transactions through mobile apps compared to a diploma, high school and higher secondary qualified respondents (Table 7).

H5: There is an effect of users' occupation on the actual usage of e-finance apps.

The results reveal that, no statistically significant difference in a number of transactions among users who differ in their occupation $(p>.001)$. The differences in the occupation of respondents do not significantly affect the number of transactions they do using mobile apps. However, the self-employed user does a higher number of the transaction using e-finance mobile apps followed by private. 
employees and student as second and third highest users respectively (Table 8).

\begin{tabular}{|l|c|c|c|c|c|c|}
\hline \multirow{2}{*}{ Occupation } & \multicolumn{7}{|c|}{ Number of transactions per month } & \multirow{2}{*}{ Total } \\
\cline { 2 - 6 } & $1-3$ & $4-6$ & $7-9$ & $10-12$ & $13-15$ & 110 \\
\hline Student & 21 & 20 & 35 & 15 & 19 & 4 \\
\hline Government Employee & 0 & 1 & 2 & 0 & 1 & 96 \\
\hline Private Employee & 8 & 8 & 16 & 29 & 35 & 127 \\
\hline Self-employed & 19 & 14 & 26 & 26 & 42 & 63 \\
\hline Others & 9 & 9 & 20 & 6 & 19 & 400 \\
\hline \multicolumn{1}{|c|}{ Total } & 57 & 52 & 99 & 76 & 116 & \\
\hline
\end{tabular}

Table 7. Cross tabulation of Occupation and Number of transactions per month

\begin{tabular}{|c|c|c|c|c|c|c|}
\hline \multirow[b]{2}{*}{ Education Qualification } & \multicolumn{5}{|c|}{ Number of transactions per month } & \multirow[b]{2}{*}{ Total } \\
\hline & $1-3$ & $4-6$ & $7-9$ & $10-12$ & $13-15$ & \\
\hline High School & 8 & 4 & 4 & 3 & 3 & 22 \\
\hline Higher Secondary & 17 & 12 & 23 & 7 & 25 & 84 \\
\hline Diploma & 7 & 7 & 11 & 4 & 6 & 35 \\
\hline Undergraduate & 16 & 16 & 35 & 37 & 32 & 136 \\
\hline Postgraduate & 9 & 13 & 26 & 25 & 50 & 123 \\
\hline Total & 57 & 52 & 99 & 76 & 116 & 400 \\
\hline
\end{tabular}

Table 6. Cross tabulation of Education qualification and Number of transactions per month

\begin{tabular}{|c|c|c|c|c|c|c|}
\hline \multirow{2}{*}{ Gender } & \multicolumn{4}{|c|}{ Number of transactions per month } & \multirow{2}{*}{ Total } \\
\cline { 2 - 6 } & $1-3$ & $4-6$ & $7-9$ & $10-12$ & $13-15$ & \\
\hline Male & 51 & 41 & 70 & 43 & 82 & 287 \\
\hline Female & 6 & 11 & 29 & 33 & 34 & 113 \\
\hline Total & 57 & 52 & 99 & 76 & 116 & 400 \\
\hline
\end{tabular}

Table 4. Cross tabulation of Gender and Number of transactions

\begin{tabular}{|c|c|c|c|c|c|c|}
\hline \multirow[b]{2}{*}{ Age } & \multicolumn{5}{|c|}{ Number of transactions per month } & \multirow[b]{2}{*}{ Total } \\
\hline & $1-3$ & $4-6$ & $7-9$ & $10-12$ & $13-15$ & \\
\hline 18 to 24 & 27 & 24 & 43 & 23 & 29 & 146 \\
\hline 25 to 30 & 13 & 11 & 26 & 24 & 31 & 105 \\
\hline 31 to 36 & 10 & 10 & 11 & 16 & 36 & 83 \\
\hline 37 to 42 & 3 & 5 & 5 & 8 & 11 & 32 \\
\hline 43 to 48 & 3 & 2 & 6 & 2 & 4 & 17 \\
\hline $49+$ & 1 & 0 & 8 & 3 & 5 & 17 \\
\hline Total & 57 & 52 & 99 & 76 & 116 & 400 \\
\hline
\end{tabular}

Table 5. Cross tabulation of Age and Number of transactions per month

\begin{tabular}{|l|c|c|c|c|c|c|}
\hline \multirow{2}{*}{ Income } & \multicolumn{7}{|c|}{ Number of transactions per month } & \multirow{2}{*}{ Total } \\
\cline { 2 - 6 } & $1-3$ & $4-6$ & $7-9$ & $10-12$ & $13-15$ & 160 \\
\hline Less than Rs.10,000 & 35 & 24 & 48 & 17 & 36 & 99 \\
\hline Rs.10,001 to Rs.15,000 & 8 & 14 & 23 & 24 & 30 & 47 \\
\hline Rs.15,001 to Rs.20,000 & 4 & 5 & 11 & 12 & 15 & 47 \\
\hline Rs.20,001 to Rs.25,000 & 4 & 4 & 13 & 12 & 14 & 47 \\
\hline More than Rs.25,000 & 6 & 5 & 4 & 11 & 21 & 400 \\
\hline Total & 57 & 52 & 99 & 76 & 116 & \\
\hline
\end{tabular}

Table 8. Cross tabulation of Income and Number of transactions per month 


\begin{tabular}{|l|c|c|}
\hline \multicolumn{1}{|c|}{ Hypothesis } & Result & p \\
\hline H1: Gender & Accepted & 0.001 \\
\hline H2: Age & Rejected & 0.118 \\
\hline H3: Income & Accepted & 0.000 \\
\hline H4: Education & Accepted & 0.000 \\
\hline H5: Occupation & Rejected & 0.108 \\
\hline
\end{tabular}

Table 9. Hypotheses Confirmation

\section{CONCLUSION}

Acceptance and usage of new emerging technology is not a choice anymore, especially in e-finance sector. An emerging digital economy in the country forces any other user to adopt these e-finance mobile apps to achieve higher financial performance. This study is an effort to find an effect of users' demographic variables on the usage of e-finance mobile apps and succeeded in many ways.

This study result ensures theoretical contribution to previous studies by achieving similar results [9], [11] and also by contradicting their findings [2], [10]. In either way, it significantly contributes to existing theories and research study results.

The findings of this study can be utilised by services provider (in this case, the e-finance mobile apps platform provider) to improve, modify or extend the existing service offerings and introduce new offerings and promotions in accordance with these findings. This can lead to an increase in overall service quality and make them a significant player in the ever expanding competitive e-finance market.

\section{LIMITATIONS AND SCOPE FOR FUTURE STUDIES}

The differences in some demographic variables in this study influencing the technology adoption and willingness to use mobile apps for all types of transactions without any fear about security risks. We only used gender, age, income, education and occupation. However, there are other demographic variables like users' marital status, family size, etc. which may be considered for future studies on technology adoption and usage. The study objective is to find an effect of users' demographic variables on actual usage of technology, this study may be extended in the future by studying the influence of demographic variables on consumer attitude or consumer behaviour.

\section{REFERENCES}

[1] Chung, J.E., Park, N., Wang, H., Fulk, J. and McLaughlin, M. (2010), Age differences in perceptions of online community participation among non-users: an extension of the technology acceptance model, Computers in Human Behavior, Vol. 26 No. 6, pp. 1674-1684.

[2] Gefen, D., \& Straub, D. (1997). Gender differences in the perception and use of email: An extension to the technology acceptance model. MIS Quarterly, 21(4), 389-400.

[3] Lam, J.C. and Lee, M.K. (2006), Digital inclusiveness - longitudinal study of internet adoption by older adults, Journal of Management Information Systems, Vol. 22 No. 4, pp. 177-206.

[4] Lee, M. C. (2009). Factors influencing the adoption of internet banking: An integration of TAM and TPB with perceived risk and perceived benefit. Electronic Commerce Research and Applications, 8(3), $130-141$.

[5] Harris, M., Cox, K.C., Musgrove, C.F., Ernstberger, K.W., (2016), Consumer preferences for banking technologies by age groups, International Journal of Bank Marketing, Vol. 34 Iss 4, pp. 587 - 602.
[6] Morris, M.G. and Venkatesh, V. (2000), Age differences in technology adoption decisions: implications for a changing workforce, Personnel Psychology, Vol. 53 No. 2, pp. 375-403.

[7] Mu, F., Climent-climent, S., \& Liébana-cabanillas, F. (2017). Determinants of intention to use the mobile banking apps: An extension of the classic TAM model. Spanish Journal of Marketing ESIC (2017) 21, 25-38.

[8] Oliveira, T., Faria, M., Thomas, M. A., \& Popovi, A. (2014). Extending the understanding of mobile banking adoption: When UTAUT meets TTF and ITM. International Journal of Information Management, 34(5), 689-703.

[9] McKeown, T., Anderson, M., (2016). UTAUT: capturing differences in undergraduate versus postgraduate learning? , Education + Training, Vol. 58 Iss 9 pp. $945-965$.

[10] Shin D.H., (2009). Towards an understanding of the consumer acceptance of mobile wallet, Computers in Human Behavior, Vol.25, pp. 1343-1354.

[11] Teo, T.S.H., (2001). Demographic and motivation variables associated with Internet usage activities. Internet Research: Electronic Networking Applications and Policy, Volume 11, Number 2, pp. 125-137.

[12] Variyar, M. (2018, January 19). Demonetisation impact? E-payments make up $60 \%$ of Amazon India's business. Retrieved February 05, 2018 ,

from https://economictimes.indiatimes.com/small-biz/startups/newsbuzz/d emonetisation-impact-e-payments-make-up-60-of-amazon-indias-bus iness/articleshow/62563623.cms

[13] Wang, Y. S., Wang, Y. M., Lin, H. H., \& Tang, T. I. (2003). Determinants of user acceptance of Internet banking: An empirical study. International Journal of Service Industry Management, 14(5), 501-519.

[14] Yu, C.S. (2012). Factors Affecting Individuals to Adopt Mobile Banking: Empirical Evidence from the UTAUT Model. Journal of Electronic Commerce Research, 13, 104-121.

\section{AUTHORS PROFILE}

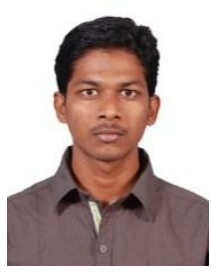

A.Monilakshmane is full-time research scholar (Ph.D.) in Department of Management Studies at Pondicherry University. He completed his bachelor degree in B.Com. (Foreign Trade) at Pondicherry University. He earned his Master's degree in M.Com. (Business Finance) and M.B.A. (International Business) at Pondicherry University. He pursuing his Ph.D. research in the field of services marketing, technology adoption, e-finance and e-commerce. He published several research papers in various sub themes of marketing management especially in new technology adoption in services marketing in UGC-listed journals and other peer reviewed journals and publications. He presented many research article and paper in national level and international level conferences. 
Factors Influence the Choice of Mobile Apps for Transactions among Youngsters

B.Rajeswari is an assistant professor in Department of Management Studies at Pondicherry University. She graduated from Tamilnadu Agricultural University in B.Sc (Agriculture). She completed M.B.A. and M.Phil. at Madurai Kamaraj University. She received Ph.D. from The Gandhigram Rural Institute (Deemed University). She has teaching experience over 15 years with area of specialization in Marketing Management, Sales \& Distribution, Retail Management, and Quality Management. Her research works has been published in International Journal of Education and Management Studies, IOSR Journal in Business and Management, Research Review: International Journal of Multidisciplinary, Global Management Review, among others. She was conducted many workshop, conferences and training programs. She has been presented various research papers in nation and international conferences. 